\title{
REFERENDUM O PREDČASNÝCH PARLAMENTNÝCH VOLBÁCH V PODMIENKACH SLOVENSKEJ REPUBLIKY
}

\section{REFERENDUM ON EARLY PARLIAMENTARY ELECTIONS IN THE SLOVAK REPUBLIC}

\author{
Monika Kajla \\ Univerzita Pavla Jozefa Šafárika v Košiciach, Právnická fakulta
}

https://doi.org/10.33542/SIC2019-1-02

\begin{abstract}
ABSTRAKT
Autor sa v tomto príspevku zameriava na inštitút celoštátneho referenda v spojitosti s inštitútom predčasných parlamentných volieb. V nadväznosti na výklad ústavnej úpravy podáva analýzu prípustnosti konania referenda o predčasných parlamentných vol'bách, posudzuje právnu silu výsledkov prijatých $v$ referende.
\end{abstract}

\begin{abstract}
Author in this contribution deals with the institute of national referendum in connection with the institute of early parliamentary elections. Following the interpretation of the constitution, he analyses the admissibility of proceedings of a referendum on early parliamentary elections, he assesses the legal value of the referendum results.
\end{abstract}

\section{I. ÚVOD}

Vo februári roku 2018 sa na Slovensku v súvislosti s vraždou investigatívneho novinára a jeho priatel'ky začal postupný proces rozpadu vlády. Aj napriek mnohým zmenám vo vládnej koalícii neutícha vo verejnosti požiadavka zásadnej rekonštrukcie vlády, resp. požiadavka predčasných parlamentných volieb. Ústava Slovenskej republiky vymedzuje viacero možností, ktorými dochádza k rozpusteniu Národnej rady Slovenskej republiky prezidentom a k následnému procesu predčasných parlamentných volieb. Ani jedna z týchto možností však explicitne neustanovuje spôsob, ktorým sa na území Slovenskej republiky konali predčasné parlamentné vol'by už trikrát, t.j. prijatím ústavného zákona, ktorým sa skracuje volebné obdobie Národnej rady Slovenskej republiky.

S otázkou predčasných parlamentných volieb vznikla aj úvaha nad konaním referenda o predčasných parlamentných vol'bách. Bola by takáto možnost' reálna? Akú záväznost' by mali výsledky prijaté v referende? Ako by mala zniet' referendová otázka?

\section{PRÍPUSTNOSŤ KONANIA REFERENDA O PREDČASNÝCH VOL’BÁCH Z HLA- DISKA JEHO VYMEDZENIA V ÚSTAVE}

Článok 95 Ústavy Slovenskej republiky č. 460/1992 Z. z. (d’alej aj „Ústava SR“ alebo „ústava") vymedzuje predmet celoštátneho referenda:

a) pozitívne - t. j. vymedzuje otázky, ktoré musia byt' predmetom referenda (tzv. obligatórne referendum), resp. otázky, ktoré predmetom referenda byt' môžu (tzv. fakultatívne referendum)

b) negatívne - t. j. vymedzuje otázky, o ktorých sa referendum nemôže konat'. 
Obligatórnost' referenda podl'a čl. 95 ods. 1 Ústavy SR spočíva v tom, že Národná rada Slovenskej republiky (d’alej aj „Národná rada SR“) musí pred schválením ústavného zákona o vstupe Slovenskej republiky do štátneho zväzku alebo o vystúpení z tohto zväzku nechat' potvrdit' tento ústavný zákon občanmi v referende. Fakultatívne referendum môže iniciovat' Národná rada Slovenskej republiky alebo ústavou stanovený počet občanov oprávnených hlasovat' $\mathrm{v}$ referende, a to v prípade iných dôležitých otázok verejného záujmu. Pojem „iné dôležité otázky verejného záujmu“ Ústava SR ani iné právne predpisy bližšie nedefinujú, preto je vždy v danom prípade potrebné posúdit', či otázka predložená na rozhodovanie v referende spadá pod túto definíciu. Možno predpokladat', že takéto posúdenie, resp. úvaha nad dôležitost'ou referendovej otázky bude v mnohých prípadoch zložitá. Samotnú možnost' konania „referenda o predčasných parlamentných vol'bách“ však jednoznačne považujem za otázku, ktorá je bez akýchkol'vek pochybností ,inou dôležitou otázkou verejného záujmu“. Uvedené si dovol'ujem tvrdit' z dôvodu, že nestabilita krajiny a nedôvera voči vrcholným predstavitel'om moci v štáte zakladá reálnu obavu verejnosti nad riadnym výkonom moci v štáte, preto je nepochybne dôležité vyriešit' formou predčasných parlamentných volieb nespokojnost' voličov a obdobie politickej destabilizácie.

Okrem pozitívneho vymedzenia predmetu referenda vymedzuje ústava aj otázky, ktoré predmetom referenda byt' nesmú. Článok 95 ods. 3 ústavy vylučuje konanie referenda o základných právach a slobodách, štátnom rozpočte, odvodoch a daniach. V spomenutom článku ústava teda taxatívne vymedzuje, ktoré otázky (aj napriek tomu, že ide o dôležité otázky verejného záujmu) nie sú spôsobilé byt' predmetom referenda.

V súvislosti s ciel'om spomenutým v úvode tohto príspevku je na mieste otázka: Nie je $z$ predmetu referenda vylúčené aj rozhodovanie občanov o predčasných parlamentných vol'bách? Nebolo by konanie referenda o otázke predčasných parlamentných volieb referendom o otázke základných práv a slobôd - konanie o otázke základného práva na prístup k voleným a iným verejným funkciám za rovnakých podmienok podl'a čl. 30 ods. 4 Ústavy SR?

V ústavnej praxi sme sa do času iniciovania „referenda o rodine“ v roku 2014 nestretli s rozhodnutím Ústavného súdu Slovenskej republiky (d’alej len „Ústavný súd SR“ alebo „ústavný súd“), ktoré by podávalo výklad článku 95 ods. 3 ústavy a tiež ani s využitím práva prezidenta Slovenskej republiky podl'a čl. 125b ods. 2 ústavy podat' ústavnému súdu návrh na rozhodnutie, či predmet referenda, ktoré sa má vyhlásit' je v súlade s ústavou alebo s ústavným zákonom. Prezident SR, Andrej Kiska toto konanie pred Ústavným súdom SR inicioval práve z dôvodu pochybností, či konanie referenda o predložených otázkach nebude spíňat' klasifikáciu referenda podl'a čl. 95 ods. 3 , t. j. klasifikáciu referenda o základných právach a slobodách. Nie je naším zámerom podávat' podrobnú analýzu otázok predložených na rozhodnutie v referende, či podrobnú analýzu rozhodnutia Ústavného súdu SR. Za dôležité považujeme poukázat' na to, že Nález Ústavného súdu Slovenskej republiky ${ }^{1} \mathrm{v}$ tejto veci podal výklad spomenutého ustanovenia ústavy, $\mathrm{v}$ tom zmysle, že konanie referenda sa $\mathrm{v}$ každom jednotlivom prípade (istým spôsobom) dotýka základných práv a slobôd, preto je nevyhnutné vykladat' toto ustanovenie ústavy tak, že konanie referenda o základných právach a slobodách je možné, ak sa tým neobmedzujú štandardy stanovené medzinárodnými dohovormi o l’udských právach a základných slobodách.

S poukazom na rozhodnutie ústavného súdu možno konštatovat', že konaniu referenda o predčasných vol’bách v zásade nebráni ustanovenie čl. 93 ods. 3 Ústavy SR, ked’že v danom

Nález Ústavného súdu Slovenskej republiky, sp. zn.: PL. ÚS 24/2014 zo dňa 28. októbra 2014. ZNUÚS 2014, s. 796, bod 36: „Ústavný súd sa preto (...) prikláňa $k$ východisku, podl’a ktorého sa prostredníctvom čl. 93 ods. 3 kladie zábrana referendám s takými otázkami, ktorých úspech by znamenal narušenie konceptu základných práv a slobôd v podobe znižovania ich štandardu vyplývajúceho z medzinárodnej úpravy i úpravy vo vnútroštátnom právnom systéme, a to v miere ohrozujúcej charakter právneho štátu. Nemožno však odmietnut' každú otázku, ktorá sa čo len minimálne obsahovo dotýka niektorého zo základných práv a slobôd. Inak by totiž skutočne došlo k popretiu zmyslu a účelu inštitútu referenda...". 
prípade nedochádza k obmedzovaniu základných práv a slobôd, ale istým spôsobom $\mathrm{k}$ ich „,narušeniu“ formou ad hoc ústavných zákonov, ktorým sa obmedzuje ich právo na výkon funkcie v zvolenom období. To či je možné, resp. prípustné formou ad hoc ústavných zákonov skracovat' funkčné obdobie poslancov Národnej rady SR bude predmetom nasledujúcej časti.

\section{PRÍPUSTNOSŤ REFERENDOVEJ OTÁZKY, MOŽNOSŤ ,SAMOROZPUSTE- NIA" NÁRODNEJ RADY SLOVENSKEJ REPUBLIKY}

Možnost' konania predčasných parlamentných volieb, resp. možnost' rozpustenia parlamentu zavádza Ústava SR v čl. 102 ods. 1 písm. e), v zmysle ktorého môže prezident rozpustit' Národnú radu Slovenskej republiky, ak Národná rada Slovenskej republiky v lehote šiestich mesiacov od vymenovania vlády Slovenskej republiky neschválila jej programové vyhlásenia, ak sa Národná rada Slovenskej republiky neuzniesla do troch mesiacovo vládnom návrhu zákona, s ktorým vláda spojila vyslovenie dôvery, ak Národná rada Slovenskej republiky nebola dlhšie ako tri mesiace spôsobilá uznášat'sa, hoci jej zasadanie nebolo prerušené a hoci bola v tom čase opakovane zvolávaná na schôdzu, alebo ak zasadanie Národnej rady Slovenskej republiky bolo prerušené na dlhši čas, ako dovoluje ústava. Prezident toto právo nemôže uplatnit'v posledných šiestich mesiacoch svojho volebného obdobia, počas vojny, vojnového stavu alebo výnimočného stavu. Prezident tiež rozpustí Národnú radu Slovenskej republiky v prípade, ak v l'udovom hlasovani o odvolani prezidenta nebol odvolaný. ${ }^{2}$

Predčasné parlamentné vol'by sa na Slovensku ani raz nekonali na podklade vyššie citovaného ustanovenia ústavy. $\mathrm{K}$ ich uskutočneniu došlo na základe prijatia ústavných zákonov, ktorými Národná rada Slovenskej republiky schválila skrátenie volebného obdobia Národnej rady a stanovila deň konania predčasných parlamentných volieb. Historicky prvý ústavný zákon o skrátení volebného obdobia Národnej rady Slovenskej republiky bol prijatý v marci roku $1994^{3}$, ktorému predchádzalo vyslovenie nedôvery vtedajšiemu predsedovi vlády SR Vladimírovi Mečiarovi a jeho následné odvolanie z funkcie predsedu vlády prezidentom Michalom Kováčom. Vo februári roku 2006 bol Národnou radou Slovenskej republiky prijatý druhý ústavný zákon o skrátení volebného obdobia ${ }^{4}$, a to v nadväznosti na odchod strany Krest'anskodemokratické hnutie z vládnej koalície. V poradí tretí a doposial' posledný ústavný zákon ${ }^{5}$, na základe ktorého došlo k uskutočneniu predčasných parlamentných volieb bol prijatý v októbri 2011, a to z dôvodu, že vtedajšia premiérka Iveta Radičová spojila hlasovanie o zmenách v eurovale (ktorý poslanci nepodporili) s hlasovaním o dôvere vláde.

Prijatie týchto ústavných zákonov vychádzalo z politických dôvodov a žiaden z nich nemal základ v referende. V histórii Slovenskej republiky sa však konali aj referendá, v ktorých sa občania vyjadrovali ku skráteniu volebného obdobia Národnej rady Slovenskej republiky, tie ale neboli úspešné. Prvé referendum o predčasných parlamentných vol'bách bolo vyhlásené v roku 2000 na základe rozhodnutia prezidenta SR, v ktorom občania rozhodovali o otázke: „Ste za to, aby sa Národná rada Slovenskej republiky uzniesla na ústavnom zákone: Volebné obdobie Národnej rady Slovenskej republiky zvolenej v roku 1998 sa skonči dňom volieb do Národnej rady Slovenskej republiky, ktoré sa vykonajú do 150 dní odo dňa vyhlásenia výsledkov referenda?". Ďalšie referendum o predčasných parlamentných vol'bách sa konalo v roku 2004. V ňom občania rozhodovali o takto formulovanej referendovej otázke: Ste za to, aby poslanci Národnej rady Slovenskej republiky prijali ústavný zákon o skrátení III. volebného obdobia Národnej rady Slovenskej republiky tak, aby sa vol'by do Národnej rady Slovenskej republiky konali v roku 2004?

\footnotetext{
Článok 102 ods. 1 písm. e) Ústavy SR č. 460/1992 Zb.

Ústavný zákon č. 70/1994 Z. z. o skrátení volebného obdobia Národnej rady Slovenskej republiky.

Ústavný zákon č. 82/2006 Z. z. o skrátení volebného obdobia Národnej rady Slovenskej republiky.

Ústavný zákon č. 330/2011 Z. z. o skrátení volebného obdobia Národnej rady Slovenskej republiky.
} 
Referendá o skrátení volebného obdobia Národnej rady SR však sprevádzali a dodnes aj sprevádzajú rozsiahle diskusie o tom, či otázka položená na rozhodnutie občanov nie je, resp. nebola $\mathrm{v}$ rozpore $\mathrm{s}$ ústavou. Citované formulácie referendových otázok možno podl'a nášho názoru napadnút' predovšetkým z dôvodu, že takúto možnost' skrátenia volebného obdobia parlamentu naša ústava explicitne neupravuje. Niektorí autori v tejto súvislosti poukazujú aj na to, že otázka predčasných parlamentných volieb ako predmetu referenda zasahuje do vzt'ahu medzi poslancom, výkonom slobodného mandátu a príkazom občanov, ktorí v platnom referende rozhodli, že si želajú prijatie ústavného zákona o skrátení volebného obdobia. ${ }^{6} \mathrm{~V}$ tejto súvislosti by bolo možno vhodnejším riešením, ak by poslanci formulovali otázku referenda $\mathrm{v}$ tom zmysle, aby na ňou potvrdzoval už prijatý ústavný zákon o skrátení volebného obdobia Národnej rady SR, obdobnou formou ako pri obligatórnom referende.

To či je v súlade s ústavou, aby sa formou ústavných zákonov skracovalo volebné obdobie poslancov Národnej rady SR bude analyzované v d’alšej časti tohto príspevku..

\section{Všeobecnost' ako základný znak právnych noriem}

Zákonodarca pri prijímaní týchto ad hoc ústavných zákonov o skrátení volebného obdobia Národnej rady SR vychádzal pravdepodobne z ustanovenia čl. 86 ods. 1 písm. a) ústavy, v zmysle ktorého do pôsobnosti Národnej rady Slovenskej republiky patrí aj právo uznášat' sa na ústave, ústavných a ostatných zákonoch

Medzi základné argumenty proti takejto forme „rozpustenia“ Národnej rady Slovenskej republiky patrí tvrdenie, že ústavnému zákonu o skrátení volebného obdobia Národnej rady SR chýba jeden zo základných znakov právnych noriem, a to všeobecnost'. Ústavní právnici poukazujú na to, že ústavný zákon o skrátení volebného obdobia nie je normatívnym právnym aktom vzt’ahujúcim sa na všeobecne vymedzený okruh adresátov a prípadov, ale individuálnym právnym aktom vzt'ahujúcim sa na konkrétne určený subjekt (Národnú radu Slovenskej republiky zvolenú na dané funkčné obdobie) a na konkrétne vymedzený prípad rozpustenia Národnej rady Slovenskej republiky. ${ }^{7}$

Prípustnost’ou rozpustenia parlamentu formou ad hoc ústavných zákonov sa zaoberal aj Ústavný súd Českej republiky (d’alej len „, Ústavný súd ČR“), ktorý nálezom PL.ÚS 27/09 zrušil ústavný zákon o skrátení volebného obdobia parlamentu a tiež rozhodnutie prezidenta o vyhlásení predčasných parlamentných volieb. V spomenutom náleze Ústavný súd ČR vyslovil, že tento ústavný zákon nespíňa požiadavku všeobecnosti právnej normy, čo považuje za podstatný rozpor s podstatnými náležitost’ami demokratického právneho štátu (čl. 9 ods. 2). ${ }^{8}$

Všeobecnost' (generalitu) ako základný a nevyhnutný znak právnych noriem potvrdil aj Ústavný súd SR vo svojej rozhodovacej činnosti, napr.: „Zákon č. 370/1994 Z. z. z legislatívnoformálnej stránky je normatívny právny akt, avšak z hl'adiska jeho predmetu, obsahu i účinkov ide o právny akt, ktorý sa v rozpore so všeobecne uznávanou požiadavkou generality vzt'ahuje na určité vopred známe jednotlivé privatizačné veci, čo princípy právneho štátu nepripúštajú.

\section{Zákaz spätného pôsobenia právnych noriem (zákaz retroaktivity)}

Pri uvažovaní o ,ústavnosti“ ad hoc ústavných zákonov o skrátení volebného obdobia Národnej rady Slovenskej republiky a možnosti ich zrušenia je nevyhnutné posúdit' aj jeden zo základných princípov právneho štátu, a to zákaz spätného pôsobenia právnych noriem (zákaz retroaktivity). Práve zákaz retroaktivity právnych noriem je definujúcim znakom právneho štátu

6 Bližšie pozri: LÁŠTIC, E.: V rukách politických strán - Referendum na Slovensku 1993-2010. Bratislava: Univerzita Ko menského v Bratislave, 2011. s. 92. ISBN: 978-80-223-3000.

7 Pozri napr. DOMIN, M.: Predčasné parlamentné vol’by. Právna teória a politická prax. In ComenIUS. 2017 [online] 20.08.2017. Dostupné na https://comenius.flaw.uniba.sk/index.php/kategorie/politika-a-pravo/29-predcasne-parlamentnevolby-pravna-teoria-a-politicka-prax.

8 Nález Ústavného súdu Českej republiky, sp. zn.: Pl. ÚS 27/09 zo dňa 10. septembra 2009. 
a významnou demokratickou zárukou ochrany práv a právnej istoty. ${ }^{9}$ Nie každá retroaktivita je však nezlučitel’ná s princípmi, na ktorých je budovaný právny štát. V určitých prípadoch teda môže právna norma pôsobit' aj spätne, retroaktívne. V teórii a praxi sa rozlišuje medzi pravou a nepravou retroaktivitou. K pravej retroaktivite dochádza vtedy, ak neskorší právny predpis neuznáva práva a povinnosti, ktoré boli nadobudnuté počas platnosti skoršieho právneho predpisu. Neskorší predpis teda upravuje vzt’ahy, ktoré sa stali v minulosti, zakladá v minulosti právne následky. To znamená, že účinnost' neskoršieho právneho aktu pri pravej retroaktivite sa začína skôr ako jeho platnost', teda v čase, ked' ešte formálne neexistoval. ${ }^{10}$ Nepravá retroaktivita predstavuje situáciu, kedy vznik právneho vzt’ahu sa posudzuje podl'a právnej normy účinnej v čase jeho vzniku, ale obsah tohto právneho vzt'ahu podl'a normy novej. ${ }^{11}$

Z teoretického vymedzenia retroaktivity je možné vyvodit', že ústavný zákon o skrátení volebného obdobia Národnej rady Slovenskej republiky pôsobí nepriamo retroaktívne, ked’že vznik právnych vzt'ahov sa posudzuje podl'a normy skoršej, ale ich obsah sa mení (t.j., že volebné obdobie parlamentu sa končí predčasne).

Vo vzt'ahu k nepriamej retroaktivite platí na isté výnimky zásada všeobecnej prípustnosti.

Ústavný súd SR sa ku (ne)prípustnosti nepriamej retroaktivity vyjadril vo svojej rozhodovacej činnosti niekol'kokrát. ,..právna úprava, ktorá , nesie“ znaky nepravej retroaktivity, môže byt' považovaná z ústavného hl'adiska za prípustnú okrem iného len vtedy, ak na jej prijatie $v$ danom prípade existovali (existujú) závažné dôvody všeobecného záujmu (legitímny verejný záujem), ktoré by ju „ospravedlňovali“ (odôvodňovali). " 12

Pri posudzovaní ústavnej akceptovatel'nosti legislatívnej zmeny, ktorá má charakter nepravej retroaktivity, treba zároveň brat' do úvahy, či v konkrétnych okolnostiach posudzovaného pripadu dôjde prijatím novej právnej úpravy zároveň aj $k$ výraznému zhoršeniu doterajšej právnej pozície dotknutých osôb (či už fyzických alebo právnických), pretože v takomto prípade je nová právna úprava minimálne v napätí s princípom ochrany legitímnych očakávaní... “ ... Nepravá retroaktivita môže ale tiež ústavne relevantným spôsobom zasiahnut' do právnej istoty, resp. do legitímnych očakávaní dotknutých subjektov práva ". ${ }^{13}$

$\mathrm{Z}$ citovaného nálezu ústavného súdu vyvstáva pre posúdenie „prípustnosti nepriamej retroaktivity“ ústavných zákonov niekol'ko otázok a možností.

Po prvé je nevyhnutné posúdit' to, či na prijatie týchto ad hoc ústavných zákonov existujú „závažné dôvody všeobecného záujmu (legitímny verejný záujem), ktoré by odôvodňovali ich prijatie." Existenciu legitímneho verejného záujmu je podl'a nášho názoru nevyhnutné skúmat' v každom jednotlivom prípade, hlavne vtedy, ked' prijatie ústavného zákona o skrátení volebného obdobia Národnej rady SR nie je iniciované zdola, ale len zo strany samotného parlamentu. Otázne je podl'a nášho názoru aj to, či prijatie ústavného zákona o skrátení volebného obdobia Národnej rady SR prijatého na podklade platného referenda je vo verejnom záujme, resp. aká čast' obyvatel'stva Slovenskej republiky by mala v takto konanom referende vyjadrit' svoj súhlas. Myslíme si, že momentálna situácia, v ktorej sa občania snažia o vyhlásenie predčasných parlamentných volieb, vychádzajú do ulíc na verejné zhromaždenia alebo inak prezentujú svoj záujem o stabilizovanie politickej situácie na Slovensku je dostatočným prejavom verejného záujmu. Pre prípustnost' nepriamej retroaktivity ústavných zákonov o skrátení volebného obdobia parlamentu je podl'a mňa postačujúce, aby referendum vyhlásené na podklade

9 JÚDA, V., SLAŠŤAN, M. Teória štátu a práva. Nitra: FF UKF, 2008. s. 299. ISBN 978-80-969-554-8-0.

10 OTTOVÁ, E. 2004. Teória práva 1. vyd. Bratislava.: Právnická fakulta Univerzity Komenského v Bratislave. s. 274. ISBN 80-7160-187-X.4.

11 BRÖSTL, A., DOBROVIČOVÁ, G, KANÁRIK, I. Teória práva. Košice: UPJŠ v Košiciach, 2007. s. 81, ISBN 978-807097-680-7.

12 Nález Ústavného súdu Slovenskej republiky, sp. zn PL. ÚS 3/2009 zo dňa 26. januára 2011.

13 Tamtiež. 
petície občanov bolo platné, resp. aby bolo rozhodnutie o predčasných vol'bách prijaté nadpolovičnou väčšinou oprávnených voličov, nakol'ko je tým nepochybne splnená podmienka „verejného záujmu" na prijatí takéhoto ústavného zákona.

Na druhej strane však vyvstáva otázka, či konanie referenda, resp. prijatie ústavného zákona o skrátení volebného obdobia Národnej rady nespôsobí „výrazné zhoršenie doterajšej pozície dotknutých subjektov", resp. či nedôjde k zásahu do princípu legitímnych očakávaní, ked’že prijatím tohto ústavného zákona zaniká mandát poslanca, a to aj takého ktorý nesúhlasil s prijatím takéhoto ústavného zákona. Do úvahy prichádza taktiež možnost' zásahu do legitímnych očakávaní voličov, ktorí si svojich zástupcov v parlamente zvolili v predčasných parlamentných vol'bách.

Zásahom do princípu legitímnych očakávaní sa zaoberal aj ústavný súd v prípade konania predčasných parlamentných volieb $\mathrm{v}$ roku 2012. Konanie predčasných parlamentných volieb v roku 2012 vyhlásených na základe ústavného zákona č. 330/2011 Z. z. o skrátení volebného obdobia Národnej rady Slovenskej republiky (d’alej aj „napadnutý ústavný zákon“), napadol ústavnou st'ažnost'ou občan Slovenskej republiky, ktorou namietal porušenie svojho základného práva zúčastňovat' sa na správe veci verejných podl'a $\S 30$ ods. 1 Ústavy SR zo strany Národnej rady Slovenskej republiky spočívajúce v prijatí napadnutého ústavného zákona, hlasovaní o tomto ústavnom zákone a $\mathrm{v}$ procese predchádzajúcom jeho prijatiu, zásahom zo strany vlády Slovenskej republiky a zásahom zo strany predsedu Národnej rady Slovenskej republiky, ktorý spočíva $\mathrm{v}$ aktoch smerujúcich $\mathrm{k}$ organizácii a ku konaniu predčasných parlamentných volieb do Národnej rady.

Ústavný súd SR v Uznesení sp. zn. II. ÚS 153/2013 z 28. februára 2013 rozhodol o odmietnutí st'ažnosti, a to z uvedených dôvodov:

- Občan Slovenskej republiky - volič, v bežných okolnostiach nie je nositel'om subjektívneho ústavného práva na ústavou stanovenú (neskrátenú) dížku volebného obdobia parlamentu

- Aj ked' predčasné parlamentné vol'by na základe ústavného zákona o skrátení volebného obdobia narušili dôveru st’ažovatel'a - voliča, v riadny výkon správy vecí verejných, neexistuje (priama) väzba medzi st'ažovatel'om a ujmou, ktorá mala byt' utrpená porušením práva na účast' na správe veci verejných, a teda st'ažovatel' nie je obet'ou porušenia ústavy.

- Prostredníctvom konania o ústavnej st’ažnosti v zásade nemožno napádat' normatívne právne akty.

Ústavný súd SR v odôvodnení tohto rozhodnutia poukázal na to, že ústavnou st’ažnost'ou nie je možné napadnút' normatívne právne akty, ked’že v zmysle $§ 127$ Ústavy SR ústavný súd rozhoduje o ústavných st'ažnostiach fyzických alebo právnických osôb, ak namietajú porušenie svojich základných práv alebo slobôd spôsobených individuálnym právnym aktom - rozhodnutím, opatrením alebo iným zásahom orgánu verejnej moci. Z načrtnutej analýzy ústavných zákonov o skrátení volebného obdobia Národnej rady Slovenskej republiky vyplýva, že týmto ústavným zákonom chýba jeden zo základných znakov právnych noriem, a to všeobecnost' (generalita). Je teda na mieste otázka, či v danom prípade Ústavný súd SR nemal skúmat' obsah tohto „normatívneho právneho aktu“, ked’že v zmysle judikatúry ústavného súdu nie je podstatná forma, ale obsah právneho aktu, a ak mu chýba jeden z podstatných znakov právnych noriem nemožno hovorit' o normatívnom právnom akte.

Z odôvodnenia Ústavného súdu SR, v zmysle ktorého neexistuje priama väzba medzi st’ažovatel'om a ujmou, ktorá mala byt' utrpená porušením práva na účast' na správe veci verejných vyvstáva otázka, ako by ústavný súd rozhodol o ústavnej st’ažnosti, ak by porušenie základných práv a slobôd namietal poslanec Národnej rady SR, ktorý hlasoval proti návrhu na vyhlásenie predčasných parlamentných volieb. V danom prípade je možné uvažovat'o zásahu do princípu 
legitímnych očakávaní, ked’že v zmysle čl. 73 ods. 1 Ústavy SR sú poslanci volení na štvorročné funkčné obdobie. Prijatím ústavného zákona o skrátení volebného obdobia Národnej rady SR sa bez priameho právneho základu v ústave končí funkčné obdobie poslancov aj napriek tomu, že ústava v čl. 81a taxatívne vymedzuje, že mandát poslanca zaniká: a) uplynutím volebného obdobia, b) vzdaním sa mandátu, c) stratou volitel’nosti, d) rozpustením Národnej rady Slovenskej republiky, e) vznikom nezlučitel'nosti podl'a čl. 77 ods. 1, f) dňom nadobudnutia právoplatnosti rozsudku, ktorým bol poslanec odsúdený za úmyselný trestný čin alebo ktorým bol poslanec odsúdený za trestný čin, a súd nerozhodol v jeho prípade o podmienečnom odložení výkonu trestu odňatia slobody. ${ }^{14}$

Z nášho pohl’adu Národná rada SR prijatím ústavných zákonov koná v rozpore s čl. 81a ústavy, nakol'ko možnost' zániku mandátu poslanca prijatím ústavného zákona o skrátení volebného obdobia ústava nezakotvuje. Uvedené by bolo možné subsumovat' pod „,rozpustenie Národnej rady Slovenskej republiky“, avšak prípad rozpustenia ústava používa v súvislosti s možnost'ou prezidenta rozpustit' Národnú radu Slovenskej republiky a nie s možnost'ou „,samorozpustenia" formou prijatia ústavného zákona o skrátení volebného obdobia Národnej rady Slovenskej republiky.

\section{ZÁVÄZNOSŤ A VYKONATELNOSŤ REFERENDA}

V súvislosti s iniciovaním referenda o predčasných vol'bách sa je potrebné zamysliet' aj nad otázkou, akú silu by malo prijatie návrhu v referende, teda ak by nadpolovičná väčšina oprávnených voličov vyjadrila súhlas s tým, aby Národná rada SR prijala ústavný zákon o skrátení volebného obdobia Národnej rady SR.

Uvedené je nevyhnutné z toho dôvodu, že ústavná a zákonná úprava inštitútu referenda vyvoláva viacero nejasností. Ústava v čl. 98 ods. 2 stanovuje, že návrhy prijaté referende vyhlási rovnako ako zákon, t.j. v rovnakom publikačnom prostriedku - Zbierke zákonov SR.

V súvislosti s návrhom prijatým v referende vyvstáva otázka vykonatel’nosti návrhu prijatého $\mathrm{v}$ referende. $\mathrm{V}$ ústavnej teórii prevládajú rôzne názory ohl'adne toho, ako by mali poslanci po schválení návrhu prijatého v referende postupovat'. Podl'a Baloga vyhlásením návrhu prijatého v referende vzniká Národnej rade SR povinnost' bez zbytočného odkladu zabezpečit', aby návrh v referende vyvolal potrebný právny účinok - teda povinnost' zabezpečit' prijatie zákona, ktorého obsahom je naplnenie, resp. vykonanie návrhu prijatého v referende. ${ }^{15}$ Čast' ústavných teoretikov však poukazuje na princíp zákazu imperatívneho mandátu poslanca, ktorý v zmysle ústavy nie je pri svojom rozhodovaní viazaný príkazmi.

Aj Ústavný súd sa v jednom zo svojich rozhodnutí vyjadril k ,„povinnosti“ poslancov Národnej rady SR hlasovat' za prijatie zákona $\mathrm{v}$ zmysle návrhu prijatého $\mathrm{v}$ referende a to $\mathrm{v}$ tom zmysle, že návrhy prijaté v referende sú pre poslancov záväzné a poslanci sú povinní konat' tak, aby v súlade s výsledkom referenda bola zmenená príslušná právna úprava. ${ }^{16} \mathrm{~V}$ neskoršom rozhodnutí Ústavný súd vyslovil názor, podla ktorého z ústavy nemožno vyvodit' povinnost' poslanca národnej rady prispiet hlasovaním $k$ tomu, aby sa návrh prijatý v referende pretvoril do adekvátnej podoby textu právneho predpisu. ${ }^{17} \mathrm{~K}$ tomuto názoru vyslovuje Balog nesúhlasné stanovisko a poukazuje na to, že poslanci sa zložením sl'ubu zaviazali pracovat' tak, aby sa ústava a ostatné zákony uvádzali do života. Ked’že ústava dovol'uje občanom rozhodnút' o dôle-

14 Článok 81 Ústavy SR č. 460/1992 Zb.

15 BALOG, B.: Charakter návrhu prijatého v referende. In Právny obzor, 98, 2015, č.5, s.497 - 512.

16 Uznesenie Ústavného súdu Slovenskej republiky, sp. zn.: II. Ú 31/97 zo dňa 21. mája 1997, cit..... Prijatie návrhu v referende má ústavnú relevanciu $v$ tom zmysle, že ním občania zúčastnení na hlasovaní udelia parlamentu prikkaz, aby $v$ súlade $s$ návrhom prijatým v referende zmenil čast' ústavy, ktorá bola predmetom vyhláseného referenda.

17 Nález Ústavného súdu Slovenskej republiky, sp. zn.: PL ÚS 24/2014 zo dňa 28. októbra 2014. 
žitej otázke verejného záujmu vzniká $\mathrm{v}$ prípade, ak tak občania $\mathrm{v}$ platnom referende urobia, povinnost' poslancov uviest' ústavu $\mathrm{v}$ tejto časti do života, a to konkrétnou legislatívnou činnost’ou. ${ }^{18} \mathrm{~S}$ vymedzeným názorom sa stotožňujeme a dodávame, že je podl'a nášho názoru neprípustné, ak by poslanci v prípade kladného výsledku referenda neprijali zodpovedajúcu právnu úpravu, resp. ak by hlasovali proti návrhom prijatým občanmi v referende, nakol'ko sú to práve občania, ktorí si poslancov zvolili do Národnej rady SR ako svojich zástupcov. V prípade ak by občania vyjadrili nespokojnost' s činnost'ou svojich zástupcov v referende o predčasných parlamentných vol'bách, resp. by súhlasili so skrátením jej volebného obdobia, majú podl'a nášho názoru poslanci z titulu toho, že im bola vyslovená nedôvera, povinnost' pretavit' výsledky referenda do legislatívnej podoby.

Okrem absencie vymedzenia záväznosti výsledkov referenda je závažnou medzerou ústavnej úpravy aj to, že Ústava SR ani zákon nezakotvuje žiaden mechanizmus, ktorý by nastupoval v prípade, ak by Národná rada SR nerešpektovala výsledky platného referenda. Z toho dôvodu je možné predpokladat', že v prípade nesúhlasu Národnej rady SR s vyhlásením predčasných parlamentných volieb schválených $\mathrm{v}$ občanmi iniciovanom referende by nebola k dispozícii žiadna možnost' občanov napadnút' toto konanie parlamentu. Dovolíme si však tvrdit', že súčasná situácia, resp. situácia politickej krízy a neutíchajúceho tlaku verejnosti na zmenu vrcholných predstavitel'ov moci je natol'ko závažná, že v a prípade ak by bolo vyhlásené referendum o predčasných parlamentných vol'bách úspešné, nevznikla by potreba mechanizmu na „donútenie“ Národnej rady SR k prijatiu takéhoto ústavného zákona.

\section{ZÁVER}

V súvislosti s politickou krízou na Slovensku sa častokrát skloňovalo a skloňuje slovné spojenie „,predčasné parlamentné vol'by“, a to aj s prípadným využitím inštitútu referenda. Menej frekventovanou témou je skutočnost', či by takéto rozhodovanie občanov vyvolalo želané výsledky.

V prvom rade si je potrebné uvedomit' to, že pre platnost' referenda je potrebné, aby sa nadpolovičná väčšina voličov zúčastnila referenda a aby bolo rozhodnutie prijaté nadpolovičnou väčšinou zúčastnených. Takto ústavne formulované kvórum sa podarilo naplnit', len v prípade rozhodovania o vstupe Slovenska do Európskej únie. Práve táto skutočnost' - t.j. evidentná neúspešnost' doposial' vykonaných referend je podl'a nášho názoru dôvodom, pre ktorý klesá záujem a účast' občanov na hlasovaní v referende. Vzhl'adom na túto skutočnost' a podiel občanov zúčastňujúcich sa parlamentných volieb si myslíme, že ani v prípade konania referenda o predčasných parlamentných vol'bách by sa nepodarilo naplnit' požadované kvórum.

Ďalšou vel'mi dôležitou skutočnost'ou je zodpovedanie otázky, či takéto skrátenie volebného obdobia Národnej rady SR, t.j. formou prijatia ústavného zákona je v súlade s princípmi právneho demokratického štátu. Prijatím ústavného zákona o skrátení volebného obdobia parlamentu dochádza k zásahu do legitímnych očakávaní tak poslancov, ako aj voličov. Dovolíme si tvrdit', že tento zásah nie je tak intenzívny, aby sme ho mohli klasifikovat' ako protiústavný, ked’že v danom prípade prevažuje záujem občanov - verejnosti nad záujmami spomenutých subjektov. Aj napriek tomu však nemožno s istotou tvrdit', že prijatie ústavného zákona vzt’ahujúceho sa na konkrétny prípad je v právnom štáte akceptovatel'né.

Vzhl'adom na vyššie vykonanú analýzu je isté, že ústavná úprava referenda a predčasných parlamentných volieb nie je postačujúca. V súčasných podmienkach bude na rozhodnutí ústavného súdu, ako rozhodne o prípadnej st’ažnosti, ktorou by sa poslanec domáhal zrušenia ústavného zákona o skrátení volebného obdobia. Sme toho názoru, že zakotvenie možnosti „samorozpustenia“"Národnej rady SR formou prijatia uznesenia do Ústavy SR, tak ako to urobili českí

18 BALOG, B.: Charakter návrhu prijatého v referende. In Právny obzor, 98, 2015, č.5, s.497 - 512. 
ústavodarcovia by bolo tým najlepším riešením. Okrem toho je nevyhnutná aj zmena ústavy SR v tom zmysle, aby v prípade referenda o predčasných parlamentných vol'bách boli ich výsledky reálne vykonatel'né.

\section{KLUUČOVÉ SLOVÁ}

referendum, predčasné parlamentné vol'by, Národná rada Slovenskej republiky

\section{KEY WORDS}

referendum, early parliamentary elections, National Council of the Slovak Republic

\section{POUŽITÁ LITERATÚRA}

1. BALOG, B.: Charakter návrhu prijatého v referende. In Právny obzor, 98, 2015, č.5, s.497 $-512$.

2. BRÖSTL, A., DOBROVIČOVÁ, G, KANÁRIK, I.: Teória práva. Košice: UPJŠ v Košiciach, 2007. ISBN 978-80-7097-680-7.

3. DOMIN, M.: Predčasné parlamentné vol'by. Právna teória a politická prax. In ComenIUS. 2017 [online] 20.08.2017. Dostupné na https://comenius.flaw.uniba.sk/index.php/kategorie/politika-a-pravo/29-predcasne-parlamentne-volby-pravna-teoria-a-politicka-prax.

4. JÚDA, V., SLAŠŤAN, M.: Teória štátu a práva. Nitra: FF UKF, 2008. s. 299. ISBN 97880-969-554-8-0.

5. LÁŠTIC, E.: V rukách politických strán - Referendum na Slovensku 1993-2010. Bratislava: Univerzita Komenského v Bratislave, 2011. s. 92. ISBN: 978-80-223-3000.

6. Nález Ústavného súdu Slovenskej republiky, sp. zn.: PL. ÚS 3/2009 zo dňa 26. januára 2011.

7. Nález Ústavného súdu Slovenskej republiky, sp. zn.: PL. ÚS 24/2014 zo dňa 28. októbra 2014.

8. Nález Ústavného súdu Českej republiky, sp. zn.: Pl. ÚS 27/09 zo dňa 10. septembra 2009.

9. OTTOVÁ, E.: Teória práva 1. vyd. Bratislava: Právnická fakulta Univerzity Komenského v Bratislave, 2004. s. 274. ISBN 80-7160-187-X.4.

10. Uznesenie Ústavného súdu Slovenskej republiky, sp. zn.: II. ÚS 31/97 zo dňa 21. mája 1997.

11. Ústava Slovenskej republiky č. 460/1992 Zb.

12. Ústavný zákon č. 70/1994 Z. z. o skrátení volebného obdobia Národnej rady Slovenskej republiky.

13. Ústavný zákon č. 82/2006 Z. z. o skrátení volebného obdobia Národnej rady Slovenskej republiky.

14. Ústavný zákon č. 330/2011 Z. z. o skrátení volebného obdobia Národnej rady Slovenskej republiky.

\section{KONTAKTNÉ ÚDAJE AUTORA}

\section{JUDr. Monika Kajla}

externá doktorandka

Univerzita Pavla Jozefa Šafárika v Košiciach, Právnická fakulta

Kováčska 26, 04075 Košice

monika.kajla@upjs.sk 